\title{
CLIMATIC SIGNATURE AND RADIOCARBON CHRONOLOGY OF MIDDLE AND LATE PLENIGLACIAL LOESS FROM EURASIA: COMPARISON WITH THE MARINE AND GREENLAND RECORDS
}

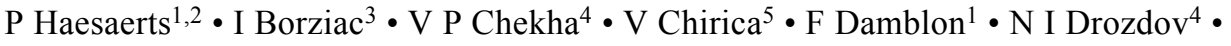 \\ L A Orlova ${ }^{6} \bullet \mathrm{S} \mathrm{Pirson}^{1} \bullet \mathrm{J}$ van der Plicht ${ }^{7}$
}

\begin{abstract}
Recent investigations devoted to the Eurasian loess formations have provided an integrated high-resolution climatic sequence well radiocarbon dated between 13.4 and $42.5 \mathrm{kyr}$ BP on charcoal and wood remains. Here, we show that the reproducible climatic signature of this loess sequence can be compared by proxy-correlation with the Greenland ice climatic signals, taking into account the distribution of the aeolian components in both records. This correlation allows situating with precision the series of ${ }^{14} \mathrm{C}$ dates obtained from loess with regard to the Greenland climatic sequence. In this way, comparing the atmospheric loess-derived ${ }^{14} \mathrm{C}$ chronology with the chronologies of the marine sequences becomes possible.
\end{abstract}

\section{INTRODUCTION}

In the course of the last decades, new data on Upper Pleistocene climate and chronology were obtained from Greenland ice records (Grootes and Stuiver 1997; Stuiver and Grootes 2000; Andersen et al. 2006; Svensson et al. 2006), as well as marine (Hughen et al. 2004; Shackleton et al. 2004) and speleothem sequences (Beck et al. 2001; Wang et al. 2001). On the continent, the main climatic information comes from lacustrine pollen records, hampered, however, by too weak a radiometric frame (de Beaulieu and Reille 1984; Reille and de Beaulieu 1990; Watts et al. 1996; Allen et al. 1999). From this follows the question of correlating continental data with the climate record in Greenland ice, which remains the best reference for Upper Pleistocene climate history in the Northern Hemisphere.

Actually, in the literature, some authors try to position a radiocarbon-dated climatic event or human occupation within an integrated Pleniglacial timescale with the aid of a statistical model using a combination of various chronological records (van Andel 1998; Jöris and Weninger 1999). However, only the IntCal04 calibration curve (Reimer et al. 2004), based on various marine and speleothem records (Bard et al. 1998, 2004; Hughen et al. 2004; Fairbanks et al. 2005), is internationally accepted. The system only holds for the period up to $26 \mathrm{kyr}$ cal BP but is still debated for the period up to $50 \mathrm{kyr}$ cal BP (van der Plicht et al. 2004).

Also, loess deposits in Eurasia, from central Europe to Siberia, have provided long sequences with good climatic markers and abundant organic material for ${ }^{14} \mathrm{C}$ dating (charcoal, wood, bone) sealed in archaeological sites (Haesaerts et al. 2003, 2005). This was an opportunity to construct long continental climatic and well-dated loess sequences with the aim at better comparing the climatic signals recorded in both the continent and the Greenland ice, the former loess deposits being under atmospheric ${ }^{14} \mathrm{C}$ conditions.

\footnotetext{
${ }^{1}$ Royal Belgian Institute of Natural Sciences, Vautier Str. 29, B-1000 Brussels, Belgium.

${ }^{2}$ Corresponding author. Email: paul.haesaerts@naturalsciences.be.

${ }^{3}$ Institute of Archaeology, Kichinau, Moldavian Republic.

${ }^{4}$ Institute of Archaeology and Ethnography, Academgorodog, 660036 Krasnoyarsk, Russia.

${ }^{5}$ Institute of Archaeology, Catargui Str. 18, 6600 Iasi, Romania.

${ }^{6}$ United Institute of Geology, Geophysics and Mineralogy, 630090 Novosibrisk, Russia.

${ }^{7}$ Centre for Isotope Research, Groningen University, Nijenborgh, 9747 AG Groningen, the Netherlands. Also: Faculty of Archaeology, Leiden University, PO Box 9515, 2300RA Leiden, the Netherlands.
}

(C) 2009 by the Arizona Board of Regents on behalf of the University of Arizona Celebrating 50 Years of Radiocarbon

RADIOCARBON, Vol 51, Nr 1, 2009, p 301-318 


\section{METHODS}

As chronology and continuity of NW European loess deposits could hardly be controlled due to the lack of organic material for ${ }^{14} \mathrm{C}$ dating (Haesaerts 1985), the loess of central Europe, with many Paleolithic occupations rich in charcoal, formed the basis for a chronological framework between 13 and 33 kyr BP set up on several hundreds of ${ }^{14} \mathrm{C}$ dates (Haesaerts et al. 2003). Later on the loess sequence of Kurtak with abundant wood remains, preserved along the Upper Yenisei (central Siberia), was included into the system in order to improve the climatic and chronological resolution of the Middle Pleniglacial record (Haesaerts et al. 2005). For each of these sequences, the reliability and accuracy of the ${ }^{14} \mathrm{C}$ dates were verified by minute control of the stratigraphic origin of the material, by strong cleaning and selection of the charcoal and wood material after identification in order to lower possible contamination, by the coherence of the whole set of dates in each sequence, and also by results obtained on marker horizons correlated between different sequences (Damblon et al. 1996).

In such a context, the climatic interpretation of the loess-paleosol records was based on the diagnosis of sedimentary and pedological processes, with special attention to periglacial phenomena, completed by pollen, mollusk, and vertebrate data when available. This approach, elaborated during the 1970s in Belgium (Haesaerts 1974; Haesaerts and Van Vliet 1974) led to a qualitative evaluation of the climatic environment ranging from present-day temperate climate to periglacial conditions with active permafrost, through boreal, subarctic, and arctic environments (Haesaerts and Van VlietLanoë 1981; Van Vliet-Lanoë 1976, 1986); loess accumulations were ascribed to dry and cold phases, while pedological horizons were considered as stabilization phases that recorded either interstadial episodes or periglacial conditions in the case of tundra gleys (Haesaerts and Van Vliet 1974; Haesaerts 1984).

Finally, it is important to stress that the correlation scheme connecting the different stratigraphic successions is fixed by the distribution of the main sedimentary units and pedocomplexes and reinforced by the sequential comparison of their climatic signatures. At this point, ${ }^{14} \mathrm{C}$ dates are taken into account to define the chronological background of the system, but also to control the consistency of the correlation scheme (Haesaerts et al. 2003).

\section{THE EAST CARPATHIAN AREA}

The main goal of our approach was to select long complementary loess records with multistratified Paleolithic occurrences rich in charcoal, preserved along main rivers and related to terrace systems acting as sediment traps at different periods of the Upper Pleistocene, the optimal resolution of each record being controlled by the sedimentary dynamics and the geomorphological position of the site. Such conditions were encountered to the east of the Carpathian foothills, along the Moldavian Plateau (Haesaerts et al. 2003; Haesaerts 2007). This area, known for its long loess successions with multiple Paleolithic settlements, is drained by the Prut and Dniester rivers, which link the Baltic plain to the steppe area around the Black Sea (Figure 1).

Three main archaeological sites, still easy to access in the 1990s, were considered (Figure 2). Cosautsi, situated along the Moldavian side of the Dniester and discovered in 1982 on top of the first terrace (Borziac 1993; Haesaerts et al. 2003), provided a high-resolution succession for the second half of the Late Pleniglacial and the Late Glacial, including at least 22 Epigravettian cultural layers. Mitoc-Malu Galben in northeast Romania, excavated since 1985 on a second terrace of the Prut, favored a pedosedimentary record during the final phase of the Middle Pleniglacial and the first half of the Late Pleniglacial, together with a large set of equally distributed Aurignacian and Gravettian workshops (Chirica 2001; Otte et al. 2007). Finally, the site of Molodova V, preserved on a 20-m ter- 


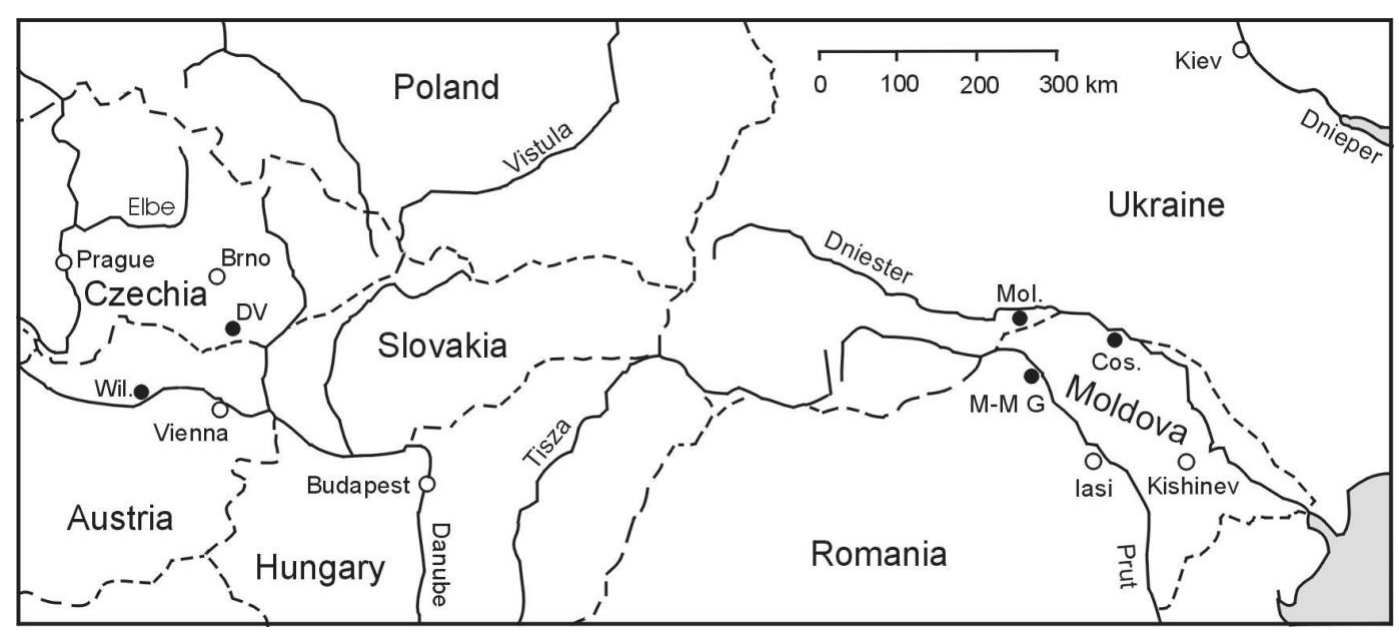

Figure 1 Location map of the sites. Wil: Willendorf; DV: Dolni Vestonice and Pavlov; Mol: Molodova; M-M G: MitocMalu Galben; Cos: Cosautsi.

race along the Ukrainian side of the Dniester, records most of the Upper Pleistocene; it provided a long pedosedimentary succession down to $50 \mathrm{kyr} \mathrm{BP}$, with several Mousterian, Gravettian, and Epigravettian layers excavated since the 1960s (Ivanova and Tzeitlin 1987; Haesaerts et al. 2003). The regional sequence elaborated from these 3 complementary successions encompasses the whole Middle and Late Pleniglacial and bears evidence of some 23 interstadial oscillations down to $\sim 50 \mathrm{kyr}$ BP, with a high chronological resolution for the time span 33-10 kyr BP distributed in 4 periods, each one lasting for around 5-6 millennia (Figures 3 and 4).

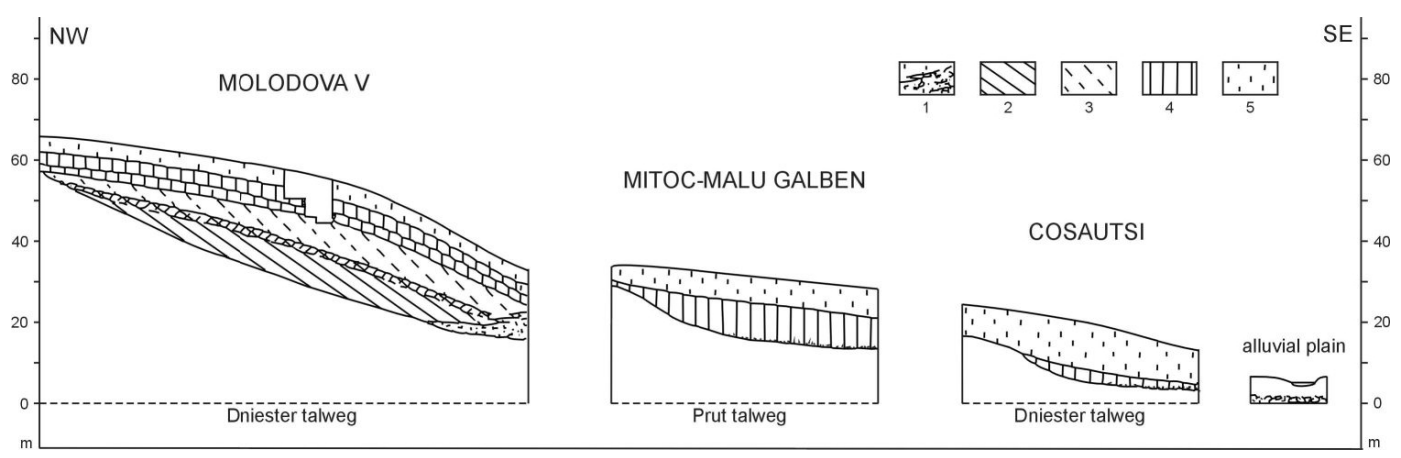

Figure 2 Geomorphological background of Molodova V, Mitoc-Malu Galben, and Cosautsi (East Carpathian Area). Graphic symbols-1: fluviatile gravels; 2: Early Glacial deposits (Molodova V: units 1 to 4); 3: Early Pleniglacial loamy loess (Molodova V: unit 5); 4: Middle Pleniglacial loess-paleosols (Molodova V: units 6 to 10; Mitoc: units 13 to 7); 5: Late Pleniglacial and Late Glacial loess.

\section{Middle Pleniglacial (About 50-26 kyr BP)}

The period between $\sim 50$ and $\sim 33 \mathrm{kyr}$ BP is only recorded at Molodova (subunit 5-2 and units 6 to 9 : Figure 3). The lower part of the Middle Pleniglacial, related to the Mousterian layers 12 to $11 \mathrm{a}$ (Chernysh 1987), consists of sandy loess with 4 humic horizons (interstadial events Molodova 5-2 and Molodova 6-1 to 6-5) dated between $\sim 50$ and $\sim 44.5 \mathrm{kyr}$ BP. They are followed by 2 loess bodies (units 7 and 9) separated by a tri-folded humic pedocomplex (unit 8) ranging from chernozern to para-rendzina. 


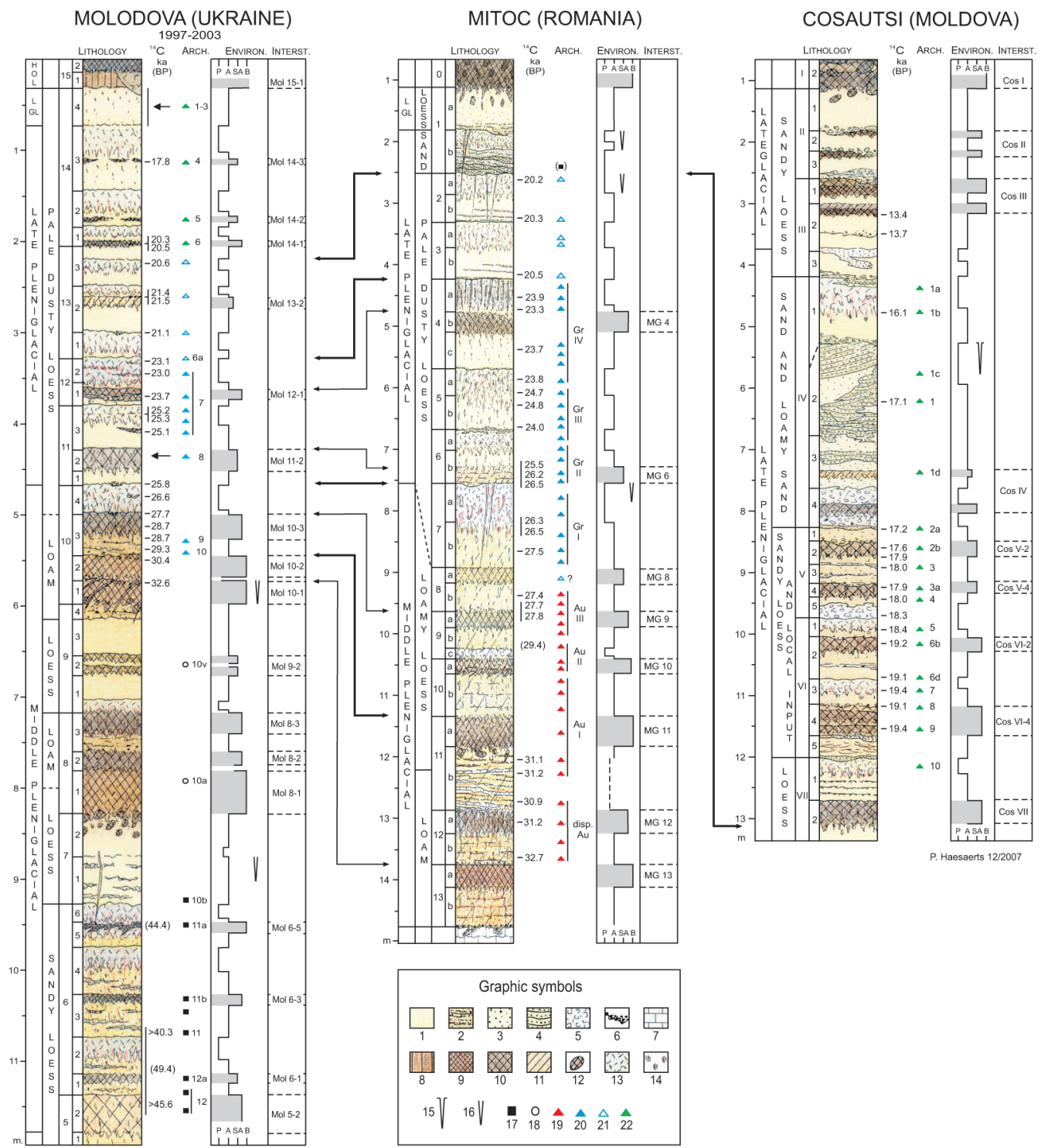

Figure 3 Main stratigraphic sequences of the East Carpathian Area. All ${ }^{14} \mathrm{C}$ dates (kyr BP) are published in Haesaerts et al. (2003). Graphic symbols for Figures 3 to 9-1: loess; 2: loam; 3: silty sand; 4: sand; 5: chalky flow; 6: gravel; 7: limestone; 8: illuviated horizon (B2); 9: strong humic horizon; 10: weak humic horizon; 11: yellowish-brown bioturbated horizon; 12: krotovinas; 13: bleached horizon (tundra gley): 14: iron staining; 15: ice-wedge cast; 16: frost wedge; 17: Mousterian; 18: transitional industries; 19: Aurignacian; 20: Gravettian; 21: poorly documented Upper Paleolithic; 22: Epigravettian. Abbreviations-Arch: archaeology; Environ: environment; P: periglacial, with deep frost or permafrost conditions; A: arctic; SA: subarctic; B: boreal; interst: interstadials; Mol: Molodova; MG: Malu Galben; Cos: Cosautsi; Gr: Gravettian; Au: Aurignacian; disp Au: dispersed Aurignacian.

The period between 33 and $26 \mathrm{kyr}$ BP corresponding to the upper part of the Middle Pleniglacial is best recorded at Mitoc-Malu Galben (units 13 to 7), underneath the Late Pleniglacial loess cover. Here, 6 humic horizons related to the interstadial events Malu Galben 13 to Malu Galben 8 alternate with loamy deposits that include an increasing aeolian component. This succession ends up by an 
important climatic pejoration with thick tundra gley well dated between 26.5 and $26.0 \mathrm{kyr}$ BP, which is usually present as a marker underneath the Late Pleniglacial loess cover in most of the key sections of central and NW Europe (Haesaerts and Van Vliet-Lanoë 1981; Haesaerts 1985). At Molodova, the period between $\sim 33$ and $26 \mathrm{kyr}$ BP fits with the upper humic pedocomplex (unit 10). It consists of 2 brown para-rendzina (subunits 10-1 and 10-2) dated 32.6 and $30.4 \mathrm{kyr}$ BP, respectively, which are equivalent to the interstadial events Malu Galben 13 and 11 (Figure 3). These soils are followed by a dark grey para-rendzina (subunit 10-3) dated between 28.7 and $27.7 \mathrm{kyr}$ BP, probably coeval to Malu Galben 10 and 9. At Molodova, unit 10 ends with a tundra gley dated between 26.6 and $25.8 \mathrm{kyr}$ BP, occurring in a similar position as the tundra gley on top of unit 7 at Mitoc.

\section{Late Pleniglacial (26 to 14 kyr BP) and Late Glacial (About 14-10 kyr BP)}

At Mitoc and Molodova, the first half of the Late Pleniglacial (from 26 to $20 \mathrm{kyr}$ BP) records the main loessic sedimentation phase with an increasing drier environment. This period includes the interstadial episodes Malu Galben 6 and Malu Galben 4, dated around 25.5 and $23.7 \mathrm{kyr}$ BP at both sites. This period is also characterized by several episodes of deep frost with tundra gleys, the most developed being dated around $23 \mathrm{kyr}$ BP. At Molodova as well as at Mitoc, the upper part of the sedimentation phase reflects a clear trend towards very dry conditions, with 2 short interstadial events (Molodova 13-2 and 14-1) dated 21.5 kyr BP and 20.4 kyr BP, respectively, at Molodova (Figure 3).

The second half of the Late Pleniglacial, between about 20 and $14 \mathrm{kyr}$ BP, is well documented at Cosautsi and partly at Molodova. During this period, a quite humid environment is prominent with locally a decrease of the loess sedimentation to the benefit of local input. Up to $\sim 17 \mathrm{kyr}$ BP, 3 doublets of interstadial humic horizons separated by 2 episodes of deep frost are dated, respectively, between 19.4 and $19 \mathrm{kyr}$ BP (Cosautsi VI-4 and VI-2), between 18 and $17.5 \mathrm{kyr}$ BP (Cosautsi V-4 and V-2), and around 17.2 kyr BP (Cosautsi IV). Further, from about 17.1 to $14 \mathrm{kyr}$ BP a drastic change of the climatic environment toward extreme conditions with several episodes of permafrost is recorded at Cosautsi (units IV-3 to IV-1) and in the upper part of the Mitoc sequence (subunit 1b). This period is characterized by intense aeolian activity and increasing sandy drift and melt-water processes related to ice-wedge casts. At the end, 2 main episodes of permafrost are marked by welldeveloped tundra gley, respectively, just after16 kyr BP and before $13.8 \mathrm{kyr}$ BP.

Finally, the Late Glacial period fits with rather dry climatic conditions related to the restart of the sandy loess sedimentation activity up to $10 \mathrm{kyr}$ BP along the Dniester Valley, but temporarily interrupted during the development of 4 humic soils reflecting boreal conditions shortly after $13.4 \mathrm{kyr}$ BP (interstadial events Cosautsi III and II).

\section{Chronological Background}

The specificity of the East Carpathian sequence rests on the opportunity we had to combine 3 complementary remarkable Paleolithic sites, each one with a nearly 14-m-thick pedosedimentary record, encompassing almost the whole Middle and Late Pleniglacial. Actually, these sites are located close to the Carpathian foothills, in favorable geographic and geomorphological contexts with forested parcels along the Prut and the Dniester valleys (Velichko 1992), which were migration routes for the herds of large herbivores during the Upper Pleistocene. This led to the semi-permanence of huntergatherers in the region during the Late Pleniglacial, including between 23 and $16 \mathrm{kyr}$ BP during the Last Glacial Maximum. Such frequent occupations were for a large part at the origin of the high chronological resolution of the regional sequence (Haesaerts et al. 2003). In such conditions, the majority of the sedimentary and climatic events of the Late Pleniglacial can be transferred from a metric scale (thickness) to the ${ }^{14} \mathrm{C}$ timescale with a precision of a few centuries as shown in Figure 4. 


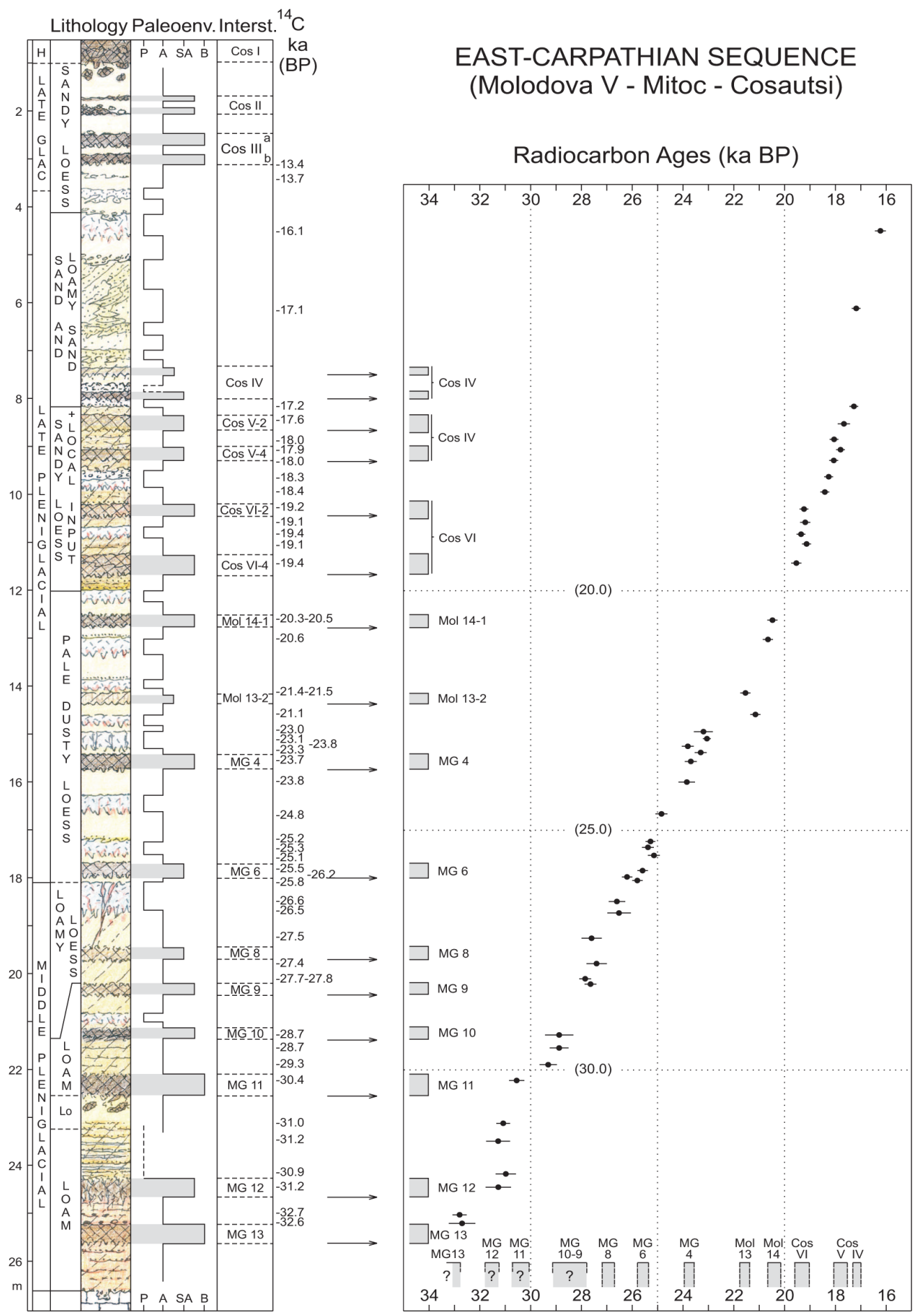

Figure 4 The East Carpathian sequence: distribution of the ${ }^{14} \mathrm{C}$ dates through time. Graphic symbols and abbreviations as in Figure 3. 
On the contrary, for the period between 26 and $\sim 33 \mathrm{kyr} \mathrm{BP}$, which climatic signature is well documented at Mitoc, the stratigraphic distribution of the available ${ }^{14} \mathrm{C}$ ages does not allow an accurate chronological framing of the climatic events for this part of the sequence. A similar situation also occurs in the Central Danube Basin where the chronological background of the Middle Pleniglacial deposits is most often constrained due to solifluction processes, as is the case at Willendorf and Dolni Vestonice (Haesaerts et al. 2007). However, the Middle Pleniglacial period could be partly completed further to the east, by the remarkable loess sequence of Kurtak in central Siberia preserved along the Yenisei to the south of Krasnoyarsk (Haesaerts et al. 2005).

\section{THE SIBERIAN SEQUENCE}

Kurtak is located on the western bank of the Krasnoyarsk Reservoir, to the north of the Minusinsk depression limited by the foothills of the Sayan Range (Figure 5), an area with strong contrast in precipitation (Haesaerts et al. 2005). At this spot, a $\sim 25$-m-thick Late Pleistocene loess-paleosol succession is largely exposed along the beach of the lake, at the edge of the Yenisei Valley slope, almost $65 \mathrm{~m}$ above the flooded alluvial plain (Chlachula 2003).

Within this succession, on the plateau the Middle Pleniglacial is represented by the Kurtak Pedocomplex developed on top of a brown boreal soil named Tcherniakovsky Soil (Figure 5). It consists of $\sim 2 \mathrm{~m}$ of loamy loess with 5 humic horizons stretched by solifluction, locally duplicated, dated on charcoal between 39 and $27.5 \mathrm{kyr}$ BP (Haesaerts et al. 2005). Laterally, the boreal soil and the Kurtak Pedocomplex often capped by a thick tundra gley, pass to the Chani Bay Complex preserved in a depression at the edge of Chani Valley. It consists, respectively, of $\sim 2$-m-thick laminated silts underlying a set of $\sim 4$-m-thick humic sandy silt deposits with abundant wood remains. Based on pedological and palynological data, the combined sequences provided a semi-continuous paleoclimatic record for the Middle Pleniglacial and put in evidence 12 positive climatic episodes of short duration named Chani I and Kurtak VIII to Kurtak Ia, well dated between 42.5 and 26 kyr BP. Humic sandy silts with abundant wood remains are deposited in the Chani depression during most of the positive episodes, recording the expansions of spruce populations in the valley, while humic horizons developed on the plateau under a steppe-like vegetation with scattered conifer trees (Haesaerts et al. 2005). On the other hand, the cold episodes are characterized by a reduced tree population in the valley and with the restart of aeolian sedimentation together with cryogenic processes on the plateau (Figure 5).

The high-resolution chronological frame of this remarkable record rests on a hundred ${ }^{14} \mathrm{C}$ dates produced in Groningen and Novosibirsk mainly on large wood remains distributed through the loesslike and humic deposits filling the Chani depression (Figure 6).

Taken together, the dates for the Kurtak Pedocomplex and Chani Bay Complex allow an excellent chronological control of the pedosedimentary processes regarding the climatic succession, with a time resolution of a few centuries for the climatic events Kurtak VIII to Kurtak Ia within the period between 39 and $26 \mathrm{kyr}$ BP (Figures 5 and 6). In this way, the Middle Pleniglacial period recorded at Kurtak can be divided into 4 distinct periods:

1. During the first period, prior to $\sim 40 \mathrm{kyr}$ BP, the Tcherniakovsky Soil of brown boreal type developed on the high parts of the landscape, under rather humid conditions, together with the deposition of the laminated silts in the Chani depression.

2. From $\sim 40$ to $\sim 33.6 \mathrm{kyr}$ BP, humic soils developed during the interstadial episodes Kurtak VIII (39 to 38 kyr BP), Kurtak VII (36.8-36 kyr), and Kurtak VI (34.5-34.3 kyr BP), while aeolian input started on the plateau during the cold episodes. 


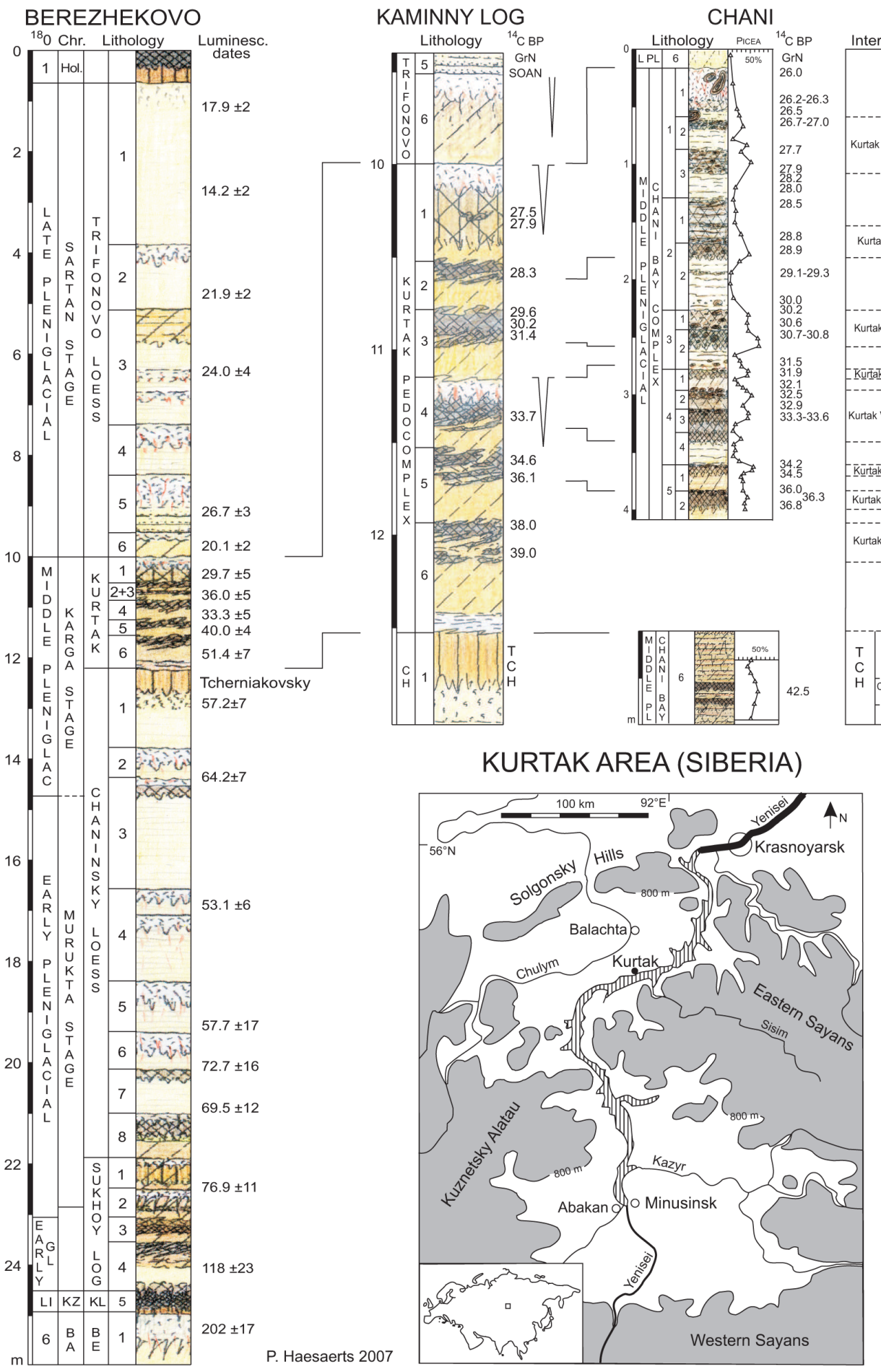

Figure 5 Late Pleistocene stratigraphic succession of the Kurtak region along the Upper Yenisei, south of Krasnoyarsk (Siberia). Luminescence dates from Zander et al. (2003); ${ }^{14} \mathrm{C}$ dates from Haesaerts et al. (2005). Graphic symbols as in Figure 3. Abbreviations - Chr: chronostratigraphy, Hol: Holocene, LI: last Interglacial, KZ: Kazan Interglacial, KL: Kaminny Log Soil; GrN: Groningen ${ }^{14} \mathrm{C}$ dates (kyr BP); SOAN: Novosibirsk ${ }^{14} \mathrm{C}$ dates (kyr BP). 


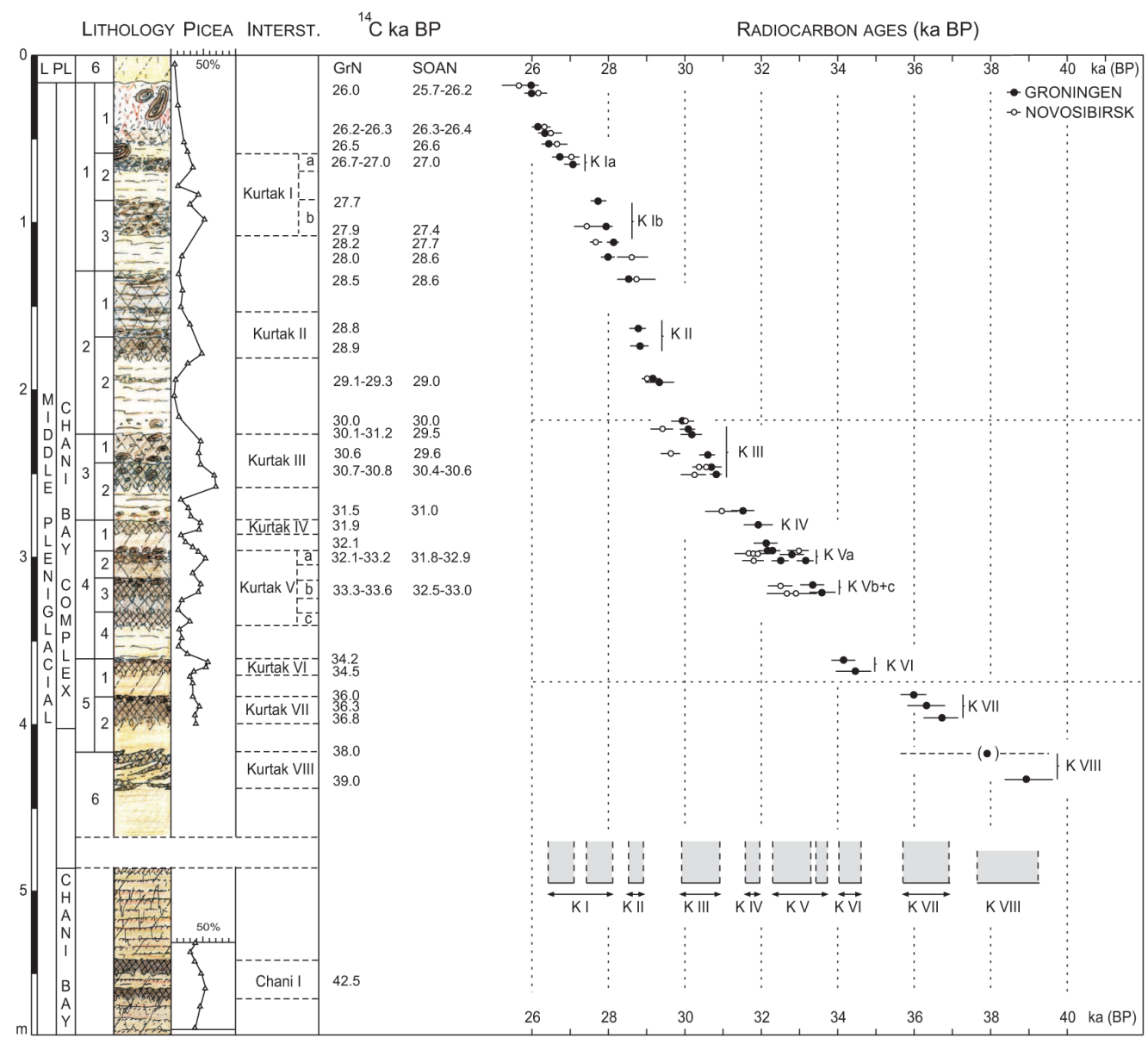

Figure 6 Integrated Middle Pleniglacial succession of Kurtak region with distribution of ${ }^{14} \mathrm{C}$ dates through time. Graphic symbols and abbreviations as in Figure 5.

3. Between about 33.6 to $31.8 \mathrm{kyr} \mathrm{BP}$, interstadial conditions were predominant during the episodes Kurtak V and Kurtak IV, with development of spruce in Chani Valley.

4. The last period between 31.8 and $26 \mathrm{kyr}$ BP records 4 interstadial episodes of decreasing intensity, respectively, Kurtak III (30.8-30 kyr BP), Kurtak II (29-28.7 kyr BP), Kurtak Ib (28-27.8 kyr BP), and Kurtak Ia (27-26.7 kyr BP). This general trend to cold conditions is also reflected by 2 episodes of permafrost with large polygonal ice wedges at $\sim 31.5 \mathrm{kyr}$ BP and $26 \mathrm{kyr}$ BP, the second one preceding the deposition of the Late Pleniglacial loess cover (Figures 5 and 6).

\section{THE INTEGRATED LOESS SEQUENCE}

The position of the Kurtak sequence with regard to the East Carpathian one is mainly founded on the climate marker that corresponds to the episode with permafrost dated close to $26 \mathrm{kyr}$ BP, well documented in both records where it precedes the first loess inputs of the Late Pleniglacial (Figure 7). On such a basis, the episodes Kurtak Ia to Kurtak III, dated between 26.7 and 30.8 kyr BP, show climatic and chronological signals directly comparable to the interstadial episodes Malu Galben 8 to 11 recorded at Mitoc. This attests to the reproducible character of these climatic events at the scale of the Eurasian continent. In return, even if they appear coherent, the correlations proposed in Figure 7 


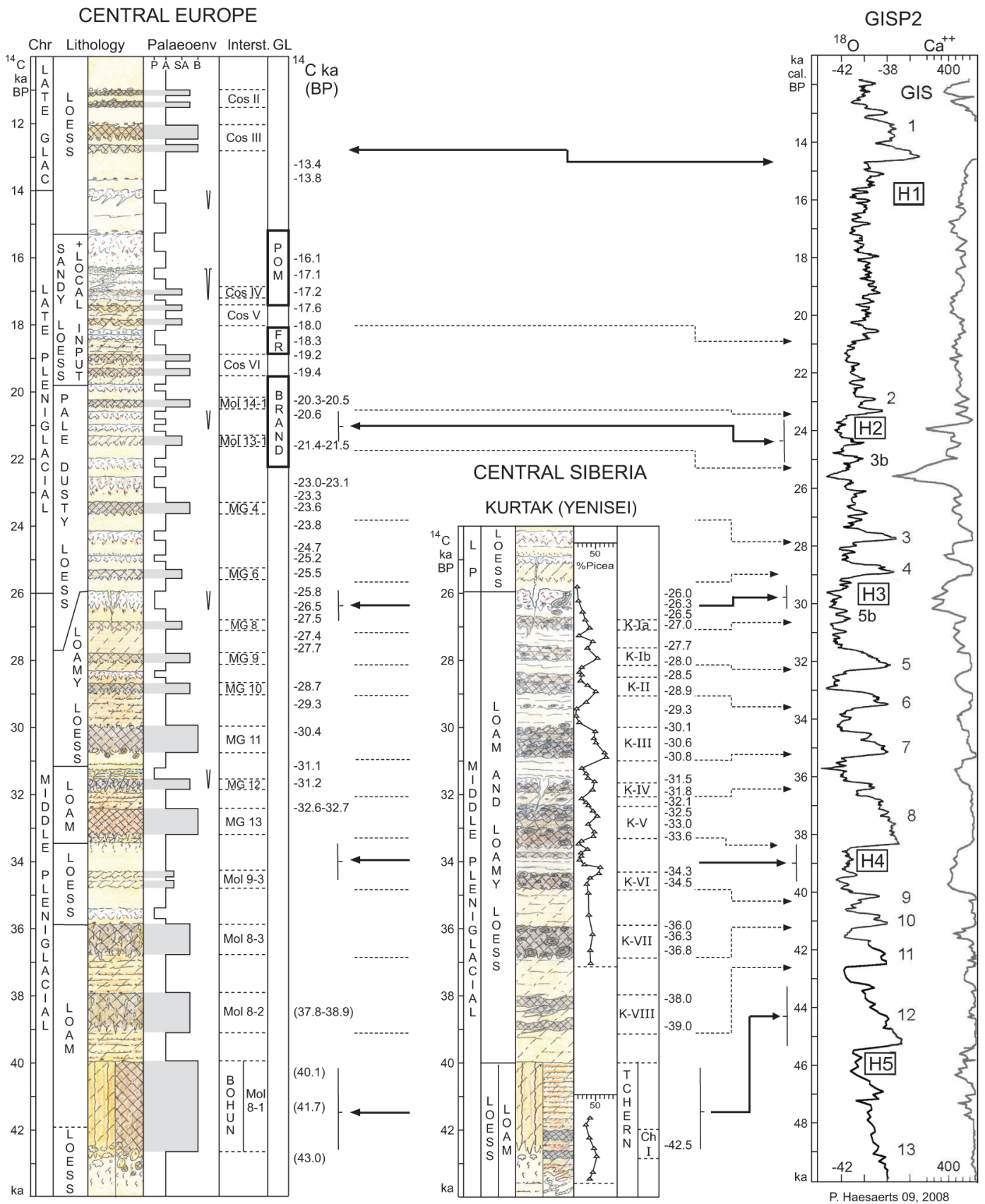

Figure 7 Proxy-correlation scheme combining the central European and Siberian loess sequences (10-46 kyr BP) with the GISP2 records (Grootes and Stuiver 1997; Meese et al. 1997; Ram and Koenig 1997). Graphic symbols as in Figure 3. Abbreviations - Chr: chronostratigraphy; Paleoenv: paleoenvironment; Interst: interstadials; Cos: Cosautsi; Mol: Molodova; MG: Malu Galben; Bohun: Bohunice; GL: Glacial extensions (northern Europe); POM: Pomeranian; FR: Frankfurt; BRAND: Brandenburg; LP: Late Pleniglacial; K: Kurtak; TCHERN: Tcherniakovsky Soil; Ch: Chani. Full horizontal lines: markers; dotted lines: lower limit of the interstadial episodes; vertical bars related to the markers: time span of the events taken into consideration. 
for the lower part of the sequence between 31 and $42.5 \mathrm{kyr}$ BP are principally based on a sequential correlation of the pedosedimentary signatures due to the limited number of chronological markers available for this period in the East Carpathian domain. In this context, notice that the interstadial episode that corresponds to Tcherniakovsky Soil dated at Chani around $42.5 \mathrm{kyr}$ BP appears in a similar position to the Molodova 8-1 interstadial. The latter has been associated with a thick chernozem-type soil that may be put in parallel with the Bohunice Soil dated between 40 and $\sim 43 \mathrm{kyr}$ BP around Brno in Moravia (Valoch 1976; Svoboda et al. 1996) and at Willendorf in Lower Austria (Haesaerts et al. 1996).

\section{COMPARISON BETWEEN LOESS AND GREENLAND ICE}

The conjunction of complementary loessic records in the East Carpathian domain and central Siberia enables to build a detailed climatic sequence for the period $42.5-10 \mathrm{kyr}$ BP. This sequence, the chronological frame of which is based on long series of coherent ${ }^{14} \mathrm{C}$ dates on high-quality charcoal and wood remains well situated in stratigraphy, is reproducible at the scale of the Eurasian continent. It represents a reference climatic record for the continental field that allows positioning the majority of the events (geological, pedological, archaeological) in the chronological scale with a resolution of a few centuries. Therefore, this sequence may be compared by proxy-correlation with the Greenland ice records insofar as both climatic signals show very strong agreements. Considering that the $\delta^{18} \mathrm{O}-$ derived cold signatures in the ice correlate with cold episodes in the terrestrial record, the ice/loess correlation is anchored using the following markers, as shown in Figure 7 (strong lines) where the loess record is compared with the GISP2 ice core, which combines climatic signals and carbonate dust (Grootes and Stuiver 1997; Meese et al. 1997; Ram and Koenig 1997).

- The base of GIS 1 is coeval to the lower limit of Cosautsi III climatic event, which records the first interstadial of the Late Glacial.

- The cold phase before GIS 2, ascribed to Heinrich event H2 (Bond et al. 1993), is connected with the upper part of the Late Pleniglacial loess cover prior to Molodova 14-1 event dated 20.4 kyr BP.

- The cold phase between GIS 4 and GIS 5b, corresponding to the H3 event, fits with the main episode of permafrost preceding the Late Pleniglacial loess; it is dated around $26 \mathrm{kyr}$ BP in the East Carpathian Area (between Malu Galben 6 and Malu Galben 8), and also at Kurtak on top of the Chani Bay Complex. Moreover, the coherence of this correlation is also strengthened by the distribution of the main loess sedimentation phases during the first half of the Late Pleniglacial, which appears in very good agreement with the maximum carbonate concentrations recorded between GIS 2 and GIS 5b in the GISP2 ice core as shown in Figure 7.

- The cold phase between GIS 8 and GIS 9, also characterized by high carbonate concentrations (H4), appears to be equivalent to the cold episode prior to $33 \mathrm{kyr}$ BP related to a main period of loess deposition at Molodova (subunit 9-3), which corresponds to the cold episode dated 33.6 to 34.3 kyr BP between the Kurtak V and Kurtak VI interstadials in Siberia.

- Finally, GIS 12, which occurs as a major climatic improvement, is put in parallel with the Tcherniakovski Soil related to the Chani I event dated around $42.5 \mathrm{kyr}$ BP in Siberia and with the Bohunice Soil in Moravia, as both pedogenesis of brown boreal type differ from the grey humiferous steppic-like soils developed after 40 kyr BP.

In such a correlation system, between the markers almost each interstadial event in the loess sequence has its equivalent in the ice (dotted lines), taking the duration of the different sedimentary and climatic episodes into account (Figures 4 and 6). For instance, GIS 2 with 3 positive peaks in $\delta^{18} \mathrm{O}$ corresponds to the interstadial events Cosautsi VI-2 and VI-4, and Molodova 14-1; it is also the 
case of GIS 3 and GIS 4, which fit with Malu Galben 4 and Malu Galben 6, respectively. In a similar way, the succession GIS $5 \mathrm{~b}$ to GIS 8 is coeval to the climatic events Kurtak Ia to Kurtak V in Siberia and Malu Galben 8 to Malu Galben 13 in central Europe. Finally, GIS 9 to GIS 11 appears to be equivalent to the succession of events Kurtak VI to Kurtak VIII.

However, concerning the Middle Pleniglacial, one should question the global representativeness and significance of the Kurtak record regarding global climate, as not only pedological features but also pollen data with strong variations in the Picea percentages could suggest regional shifts of humidity in the environment (Haesaerts et al. 2005:18).

Nevertheless, the comparative scheme of Figure 8 shows that the climatic events recorded at Kurtak for the period 26-42.5 kyr BP appear coherent with the distribution of the main climatic events recorded in the Greenland ice, as well as in the marine sequences of Cariaco (Hughen et al. 2004), Iberian Margin (Shackleton et al. 2004), and Iceland Sea (van Krefeld et al. 2000), which were compared to the GISP2 sequence. In this scheme, the chronological distribution of the main interstadial episodes of the loess sequence shows ${ }^{14} \mathrm{C}$ ages that are comparable to the ones obtained for the marine records, taking into account the chronological shifts related to the reservoir effect.

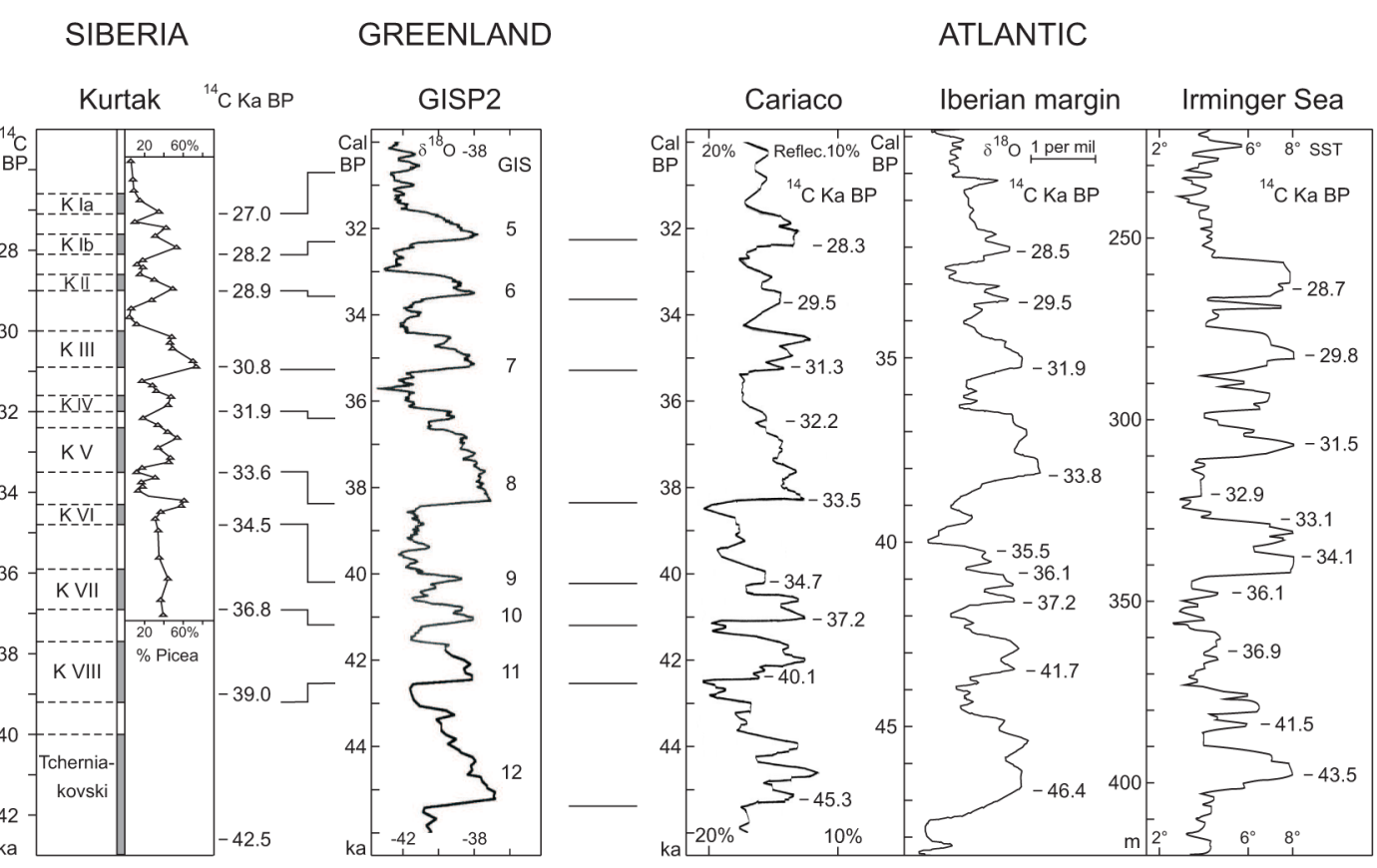

Figure 8 Distribution through time (26-42.5 kyr BP) of the interstadial episodes at Kurtak compared to the GISP2 record (Grootes and Stuiver 1997; Meese et al. 1997) and to the marine records from Cariaco (Hughen et al. 2004), Iberian Margin (Shackleton et al. 2004), and Irminger Sea (van Krefeld et al. 2000). All ages (kyr BP) related to the base of the climatic episodes are uncalibrated ${ }^{14} \mathrm{C}$ dates.

\section{DISCUSSION AND CONCLUSIONS}

Considering the proposed correlation between the loess and the Greenland ice records, the next step consisted in plotting the atmospheric ${ }^{14} \mathrm{C}$ dates with regard to the Greenland climatic signal; therefore, the specificity of the ${ }^{14} \mathrm{C}$-dated material and its relation with the event to be dated must be considered. 
Concerning the Late Pleniglacial of the East Carpathian Area, almost all dates were produced on charcoal from archaeological layers, within a semi-continuous succession of pedosedimentary events with a high rate of sedimentation between 26 and $17.2 \mathrm{kyr}$ BP, as demonstrated in Figure 4. In such a system, the position of a charcoal cluster, on top or in the middle of a humic horizon, will have little effect on the ${ }^{14} \mathrm{C}$ age of the corresponding interstadial episode, which did not exceed a few centuries taking the ${ }^{14} \mathrm{C}$ measurement uncertainty into account.

In this way, the dated samples that were associated with these short interstadial episodes have been positioned on the whole duration of each corresponding short positive ${ }^{18} \mathrm{O}$ event into the climatic sequence of GISP2 as shown in Figure 9. Further, positioning dated samples from loess in the GISP2 sequence was made with regard to the tundra gleys associated with deep frost events, which are marked by minimum peaks in the oxygen curve.

\section{EAST CARPATHIANS}

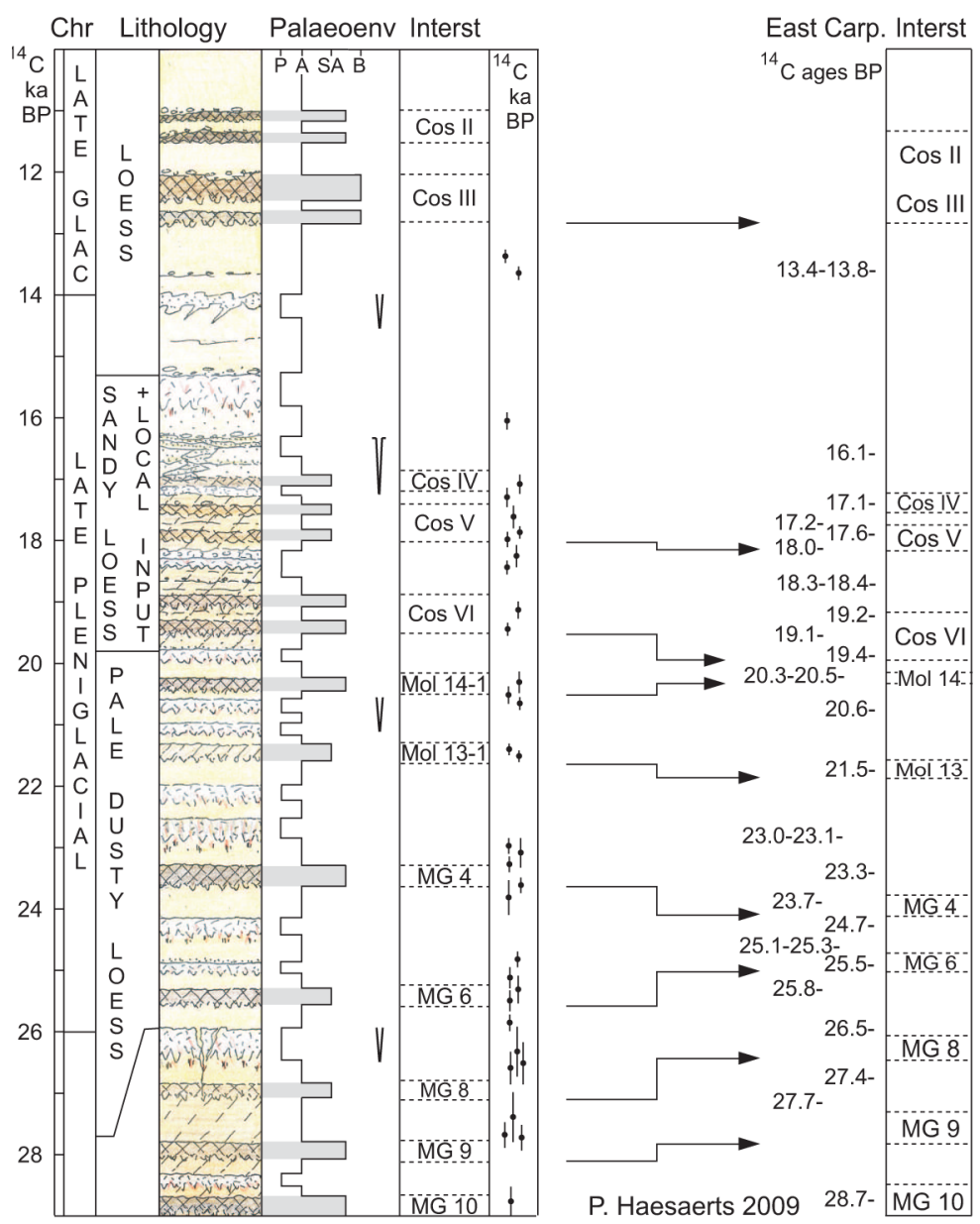

GISP2

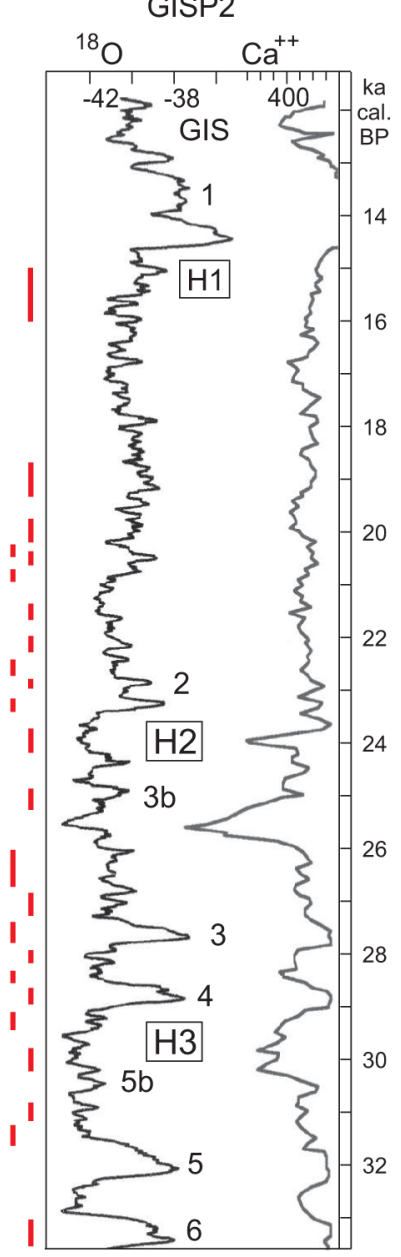

Figure 9 Proxy-correlation between the East Carpathian climatic sequence and GISP2. The vertical bars along the East Carpathian record correspond to the ${ }^{14} \mathrm{C}$ dates (kyr BP) with measurement uncertainty. The vertical bars along the GISP2 sequence show the degree of uncertainty of inferred position of the dated samples into the climatic record of the Greenland ice. Graphic symbols and abbreviations as in Figures 3 and 7. 
On the contrary, such an approach is more problematic when considering the ${ }^{14} \mathrm{C}$ dates at disposal for the Middle Pleniglacial interstadial events Malu Galben 8 to Malu Galben 13 dated between 26 and $\sim 33 \mathrm{kyr} \mathrm{BP}$, which lasted at least 1 millennium or longer (Figures 4 and 7). Nevertheless, a much better situation is encountered at Kurtak, where most of the ${ }^{14} \mathrm{C}$-dated wood remains were buried during the sedimentation of the humic silts related to the interstadial episodes Kurtak Ia to Kurtak VII. In this context, the consistent succession of the ${ }^{14} \mathrm{C}$ dates allows a precise chronological control of the climatic events to which they belong (Figure 6), provided that the coherence of the ages confirm a very low reworking of the wood remains from the slopes, probably linked to a progressive imprint of frost during the sedimentation phases (Haesaerts et al. 2005:22). As a consequence, most of the ${ }^{14} \mathrm{C}$ dates from Kurtak could be precisely situated regarding the base, the middle or the top of the corresponding climatic events in the Greenland ice as shown in Figure 10.

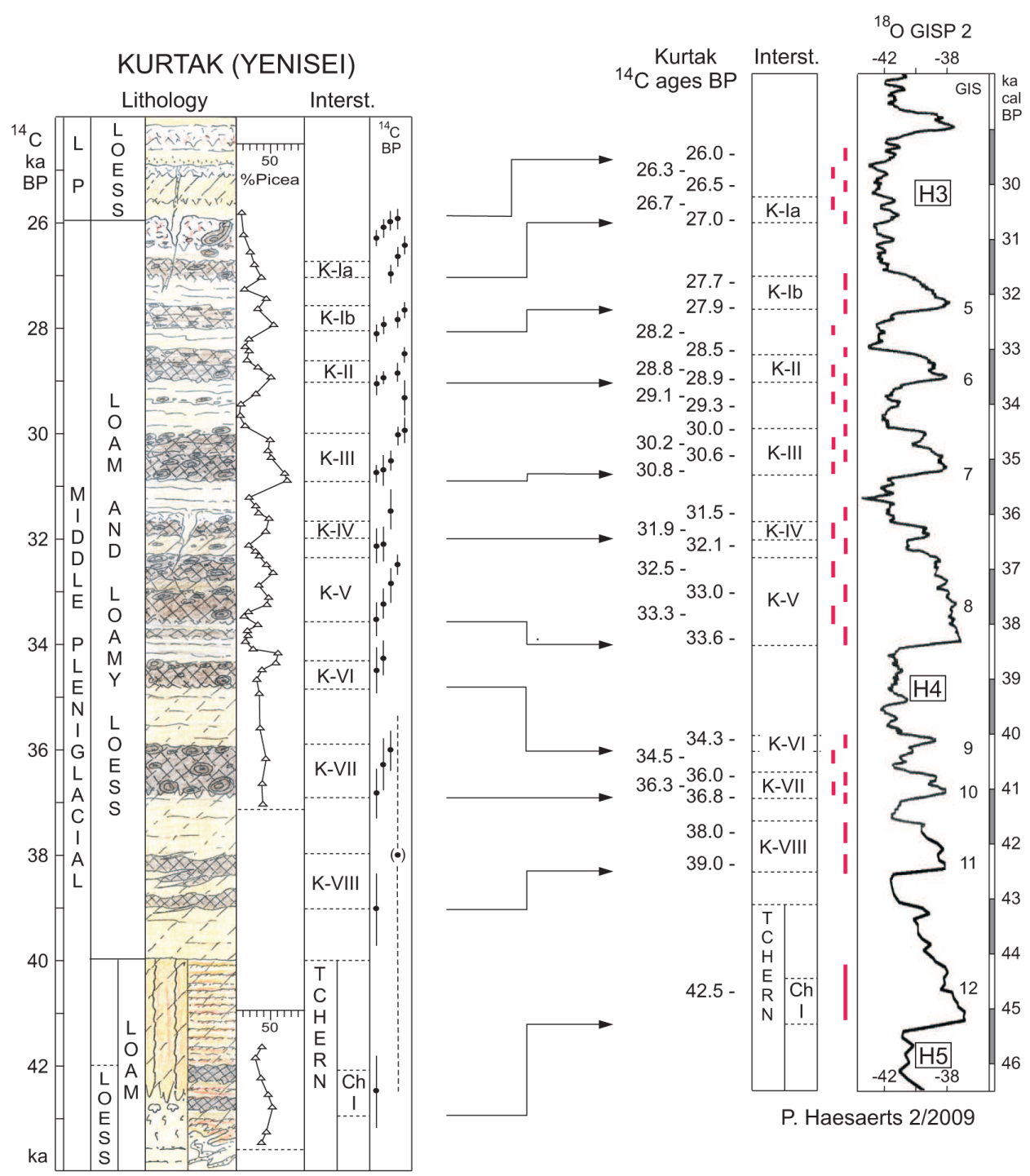

Figure 10 Proxy-correlation between the climatic events at Kurtak and GISP2 with inferred position of the Kurtak ${ }^{14} \mathrm{C}$ dates (kyr BP) regarding the climatic record of the ice (cf. caption Figure 9). 
Keeping in mind the points discussed above, the ${ }^{14} \mathrm{C}$ dates obtained for the Late Pleniglacial sequence of the East Carpathian Area and for the Middle Pleniglacial record at Kurtak are plotted separately on the graphs of Figure 11 with regard t the GISP2 climatic sequence. For comparison,
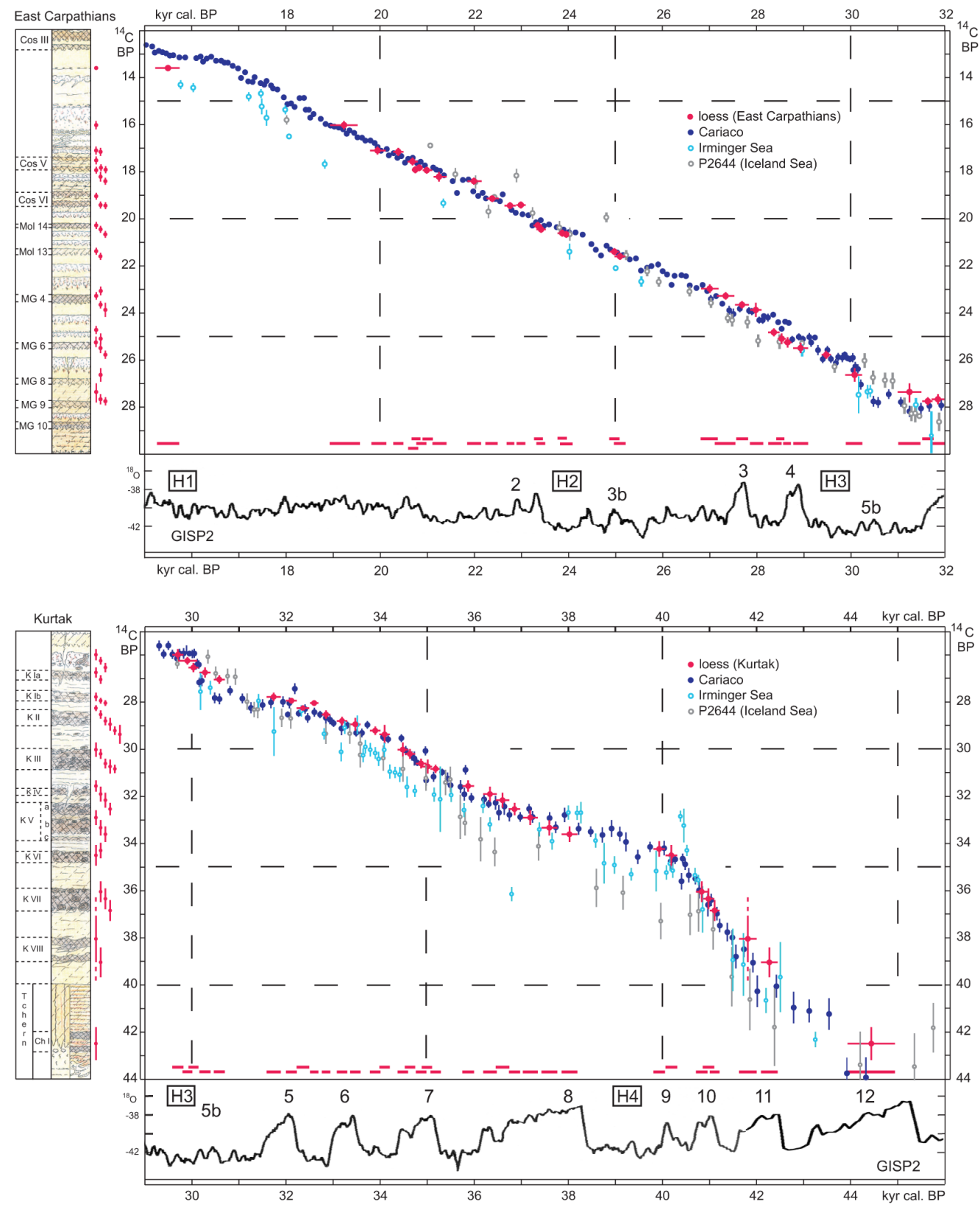

Figure 11 Distribution of the atmospheric ${ }^{14} \mathrm{C}$ dates from the East Carpathian Area (above) and Kurtak (below) regarding the GISP2 climatic sequence (as in Figures 9 and 10), compared to the distribution of the ${ }^{14} \mathrm{C}$ dates from the marine sequences of Cariaco (Hughen et al. 2004, 2006), Irminger Sea (van Krefeld et al. 2000), and Iceland Sea (Voelker et al. 2000). Graphic symbols as in Figure 3. The red vertical bars along the loess sequences correspond to ${ }^{14} \mathrm{C}$ dates (kyr BP) with uncertainty. The red horizontal bars along the GISP2 sequence show the degree of uncertainty of inferred position of the dated samples from the loess into the climatic record of Greenland ice. 
on the same graphs, we also show the distribution of the ${ }^{14} \mathrm{C}$ dates obtained on foraminifera from Cariaco (Hughen et al. 2004), Irminger Sea (van Krefeld et al. 2000), and Iceland Sea (Voelker et al. 2000) with a reservoir effect correction of $420 \mathrm{yr}$. In this system, the link between these 3 sets of marine ${ }^{14} \mathrm{C}$ dates on the one hand and the atmospheric ${ }^{14} \mathrm{C}$ dates from the loess on the other hand is only related to their position within the GISP2 climatic sequence, and not to its chronological scale. In such a way, strong similarities between the distribution of the ${ }^{14} \mathrm{C}$ dates from the loess and from the Cariaco record clearly appear, in particular between 26 and 42 kyr BP (GISP2 calendar timescale), while the distribution of the dates from Irminger Sea and Iceland Sea diverge considerably downwards from 30 cal kyr BP (Figure 11).

Consequently, these similarities regarding the link between Cariaco and GISP2 confirm in an independent way the proposed proxy-correlation between the high-resolution climatic sequence of the loess and the Greenland ice record. Such similarities also question the reproducibility of the eventual important variations in the ${ }^{14} \mathrm{C}$ concentration of the atmosphere between 32 and $45 \mathrm{kyr}$ calendar BP as supposedly recorded in the Iceland and Irminger Sea sequences (Conard and Bolus 2003).

Finally, for the first time, we have the opportunity to compare a robust chronological sequence based on reliable long series of atmospheric ${ }^{14} \mathrm{C}$ dates obtained for loess with the Greenland records. Such an approach is different from calibration, avoiding to propose an illusory absolute age; on the contrary, our purpose aims at correlating any climatic event or archaeological occurrence precisely positioned in the continental ${ }^{14} \mathrm{C}$ chronology, with the climatic signatures of the Greenland ice records, regardless of their chronological frames (cf. Svensson et al. 2006: Figure 1). This process is directly a matter of climatostratigraphy as a fundamental method in Quaternary research (Salvador 1994).

\section{ACKNOWLEDGMENTS}

The approach combining loess, archaeology, and radiocarbon dating was initiated during the 1960s by Jean de Heinzelin (Belgium) and Bohuslav Klima (Moravia). It was further developed thanks to the experience of our colleagues and friends from central Europe, Russia, and Siberia. The illustration were carried out by Eric Dermience (RBINS). We also thank Paula Reimer for her relevant comments. This work is a contribution to the Sc-004 and Sc-09 projects initiated by the Belgian State, Federal Office for Scientific, Technical and Cultural Affairs. Complementary funding was provided by INTAS 93-1693 and 93-1693-Ext projects and by INTAS 96-0072 and 2000-879 projects.

\section{REFERENCES}

Allen JRM, Brandt U, Brauer A, Hubberten H-W, Huntley B, Keller J, Kraml M, Mckensen A, Mingram J, Negendank JFW, Nowaczyk NR, Oberhänsli H, Watts WA, Wulf S, Zolitschka B. 1999. Rapid environmental changes in southern Europe during the last glacial period. Nature 400(6746):740-3.

Andersen KK, Svensson A, Johnsen SJ, Rasmussen SO, Bigler M, Rothlisberger R, Ruth U, Siggaard-Andersen ML, Steffensen JP, Dahl-Jensen D, Vinther BM, Clausen HB. 2006. The Greenland Ice Core chronology 2005, 15-42 ka. Part 1: constructing the time scale. Quaternary Science Reviews 25(23-24):3246-57.

Bard E, Arnold M, Hamelin B, Tisnerat-Laborde N, Cabioch G. 1998. Radiocarbon calibration by means of mass spectometric ${ }^{230} \mathrm{Th} /{ }^{234} \mathrm{U}$ and ${ }^{14} \mathrm{C}$ ages of corals: an updated database including samples from Barba- dos, Mururoa and Tahiti. Radiocarbon 40(3):1085-92. Bard E, Rostek F, Ménot-Combes G. 2004. Radiocarbon calibration beyond 20,000 year ${ }^{14} \mathrm{C}$ B.P. by means of planktonic foraminifera of the Iberian Margin. Quaternary Research 61(2):204-14.

Beck JW, Richards DA, Edward RL, Silverman BW, Smart PL, Donahue DJ, Herrera-Osterheld S, Burr GS, Calsoyas L, Jull ATJ, Biddulph D. 2001. Extremely large variations of atmospheric ${ }^{14} \mathrm{C}$ concentration during the last glacial period. Science 292(5526): 2453-8.

Bond G, Broecker W, Johnsen S, McManus J, Labeyrie L, Jouzel J, Bonani G. 1993. Correlations between climate from North Atlantic sediments and Greenland ice. Nature 365(6442):143-7.

Borziac IA. 1993. Les chasseurs de renne de Kosoioutsy, 
site paléolithique tardif à plusieurs niveaux sur le Dniestr moyen (rapport préliminaire). L'anthropologie (Paris) 97(2-3):331-6. In French.

Chernysh AP. 1987. The standard multilayered site Molodova V. Archaeology. In: Ivanova IK, Tzeitlin $\mathrm{SM}$, editors. The Multilayered Palaeolithic Site Molodova V. The Stone Men and Environment. Moscow: Nauka. p 7-93. In Russian.

Chirica V. 2001. Gisements paléolithiques de Mitoc. Le Paléolithique Supérieur de Roumanie à la lumière des découvertes de Mitoc. Bibliotheca Archaeologica Iassiensis (Iasi) 11.216 p. In French.

Chlachula J. 2003. The Siberian loess record and its significance for reconstruction of Pleistocene climate in north-central Asia. Quaternary Science Reviews 22(18-19):1879-906.

Conard NJ, Bolus M. 2003. Radiocarbon dating and the appearance of modern humans and timing of cultural innovations in Europe: new results and new challenges. Journal of Human Evolution 44(3):331-71.

Damblon F, Haesaerts P, van der Plicht J. 1996. New datings and considerations on the chronology of Upper Palaeolithic sites in the Great Eurasian Plain. Préhistoire Européenne 9:177-231.

de Beaulieu J-L, Reille M. 1984. A long Upper Pleistocene pollen record from Les Echets, near Lyon, France. Boreas 13(2):111-32.

Fairbanks RG, Mortlock RA, Chiu T-C, Cao L, Kaplan A, Guilderson TP, Fairbanks TW, Bloom AL, Grootes PM, Nadeau M-J. 2005. Radiocarbon calibration curve spanning 0 to 50,000 years BP based on paired ${ }^{230} \mathrm{Th} /{ }^{234} \mathrm{U} /{ }^{238} \mathrm{U}$ and ${ }^{14} \mathrm{C}$ dates on pristine corals. Quaternary Science Reviews 24(16-17):1781-96.

Grootes PM, Stuiver M. 1997. Oxygen 18/16 variability in Greenland snow and ice with $10^{-3}$ to $10^{-5}$-year time resolution. Journal of Geophysical Research 102(C12):26,455-70.

Haesaerts P. 1974. Séquences paléoclimatiques du Pléistocène supérieur du bassin de la Haine. Annales de la Société géologique de Belgique (Liège) 97:105-37. In French.

Haesaerts P. 1984. Stratigraphic distribution of periglacial features indicative of permafrost in the Upper Pleistocene loesses of Belgium. In: Permafrost, Fourth International Conference, Proceedings. Washington DC: National Academy Press. p 421-6.

Haesaerts P. 1985. Les loess du Pléistocène supérieur en Belgique. Comparaisons avec les séquences d'Europe centrale. Bulletin de l'Association Française pour l'Etude du Quaternaire (Paris) 22-23(2-3):105-15. In French.

Haesaerts P. 2007. Mitoc-Malu Galben: cadre stratigraphique et chronologique. In: Otte M, Haesaerts $\mathrm{P}$, Chirica V, editors. L'Aurignacien et le Gravettien de Mitoc-Malu Galben (Moldavie roumaine). Liège: ERAUL. p 15-41. In French.

Haesaerts P, Van Vliet B. 1974. Compte rendu de l'excur- sion du 25 mai 1974 consacrée à la stratigraphie des limons aux environs de Mons. Annales de la Société Géologique de Belgique (Liège) 97:547-60. In French.

Haesaerts P, Van Vliet-Lanoë B. 1981. Phénomènes périglaciaires observés à Harmignies, à Maisières-Canal et à Rocourt (Belgique). Biuletyn Peryglacjalny (Lodz) 28:291-324. In French.

Haesaerts P, Damblon F, Bachner M, Trnka G. 1996. Revised stratigraphy and chronology of the Willendorf II sequence, Lower Austria. Archaeologia Austriaca (Vienna) 80:25-42.

Haesaerts P, Borziac IA, Chirica V, Damblon F, Koulakovska L, van der Plicht J. 2003. The East Carpathian loess record: a reference for the middle and late pleniglacial stratigraphy in central Europe. Quaternaire (Paris) 14(3):163-88. http://quaternaire.revues.org/.

Haesaerts P, Chekha VP, Damblon F, Drozdov NI, Orlova LA, van der Plicht J. 2005. The loess-palaeosol succession of Kurtak (Yenisei Basin, Siberia): a reference record for the Karga Stage (MIS 3). Quaternaire (Paris) 16(1):3-24. http://quaternaire.revues.org/.

Haesaerts P, Borziac IA, Chirica V, Damblon F, Koulakovska L. 2007. Cadre stratigraphique et chronologique du Gravettien en Europe centrale. Paléo (Bordeaux) 19:29-50. In French.

Hughen KA, Lehman S, Southon J, Overpeck J, Marchal O, Herring C, Turnbull J. 2004. ${ }^{14} \mathrm{C}$ activity and global carbon cycle changes over the part 50,000 years. Science 303(5655):202-7.

Hughen KA, Southon J, Lehman S, Bertrand C, Turnbull J. 2006. Marine-derived ${ }^{14} \mathrm{C}$ calibration and activity record for the past 50,000 years updated for the Cariaco Basin. Quaternary Science Reviews 25(23-24): 3216-27.

Ivanova IK, Tzeitlin SM. 1987. The Multilayered Palaeolithic Site Molodova V. The Stone Men and Environment. Moscow: Nauka. 187 p. In Russian.

Jöris O, Weninger B. 1999. Possibilities of calendric conversion of radiocarbon data for the glacial periods. In: Evin J, Oberlin C, Daugas JP, Salles JF, editors. Actes du 3ème congrès international Archéologie et ${ }^{14} \mathrm{C}$, Lyon, 6-10 avril 1998. Mémoires de la Societé Préhistorique Française 26:87-92.

Meese DA, Gow AJ, Alley RB, Zielinski GA, Grootes PM, Ram M, Taylor KC, Mayewski PA, Bolzan JF. 1997. The Greenland Ice Sheet Project 2 depth-age scale: methods and results. Journal of Geophysical Research 102(C12) 26:411-23.

Otte M, Haesaerts P, Chirica V, editors. 2007. L'Aurignacien et le Gravettien de Mitoc-Malu Galben (Moldavie roumaine). Liège: ERAUL. 233 p. In French.

Ram M, Koenig G. 1997. Continuous dust concentration profile of pre-Holocene ice from the Greenland Ice Sheet Project 2 ice core: dust stadials, interstadials, and Eemian. Journal of Geophysical Research 102(C12):26,641-8. 
Reille M, de Beaulieu J-L. 1990. Pollen analysis of a long Upper Pleistocene continental sequence in a Velay maar (Massif Central, France). Palaeogeography, Palaeoclimatology, Palaeoecology 80(1):35-48.

Reimer PJ, Hughen KA, Guilderson TP, McCormac G, Baillie MGL, Bard E, Barratt P, Beck JW, Buck CE, Damon PE, Friedrich M, Kromer B, Bronk Ramsey C, Reimer RW, Remmele S, Southon JR, Stuiver M, van der Plicht J. 2004. Preliminary report of the first workshop of the IntCal04 radiocarbon comparison/calibration working group. Radiocarbon 44(3):653-61.

Salvador A, editor. 1994. International Stratigraphic Guide. A Guide to Stratigraphic Classification, Terminology, and Procedure. 2nd edition. Boulder: Geological Society of America. 214 p.

Shackleton NJ, Fairbanks RG, Chiu T-C, Parrenin F. 2004. Absolute calibration of the Greenland time scale: implications for Antarctic time scales and for $\Delta^{14} \mathrm{C}$. Quaternary Science Reviews 23(14-15):1513-22.

Stuiver M, Grootes PM. 2000. GISP oxygen isotope ratios. Quaternary Research 53(3):277-84.

Svensson A, Andersen KK, Bigler M, Clausen HB, DahlJensen D, Davies SM, Johnsen SJ, Muscheler R, Rasmussen SO, Röthlisberger R, Steffsensen JP, Vinther BM. 2006. The Greenland Ice Core Chronology 2005, 15-42 ka. Part 2: comparison to other records. Quaternary Science Reviews 25(23-24):3258-67.

Svoboda J, Ložek V, Vlček E. 1996. Hunters between East and West: The Paleolithic of Moravia. New York: Plenum. 295 p.

Valoch K. 1976. Die altsteinzeitliche Fundstelle in BrnoBohunice. Brno: Ceskoslovenske Akademie ved Studie Archeologickeho ustavu Ceskoslovenske Akademie ved v brne, 4. 120 p. In German.

van Andel TH. 1998. Middle and Upper Palaeolithic environments and the calibration of ${ }^{14} \mathrm{C}$ dates beyond 10,000 BP. Antiquity 72(275):26-33.

van der Plicht J, Beck JW, Bard E, Baillie MGL, Blackwell PG, Buck CE, Friedrich M, Guilderson TP, Hughen KA, Kromer B, McCormac FG, Bronk Ramsey C, Reimer PJ, Reimer RW, Remmele S, Richards DA, Southon JR, Stuiver M, Weyhenmeyer CE. 2004.
NotCal04 - comparison/calibration ${ }^{14} \mathrm{C}$ records 26 50 cal kyr BP. Radiocarbon 46(3):1225-38.

van Krefeld S, Sarnthein M, Erlenkeuser H, Grootes P, Jung S, Nadeau M-J, Pflaumann U, Voelker A. 2000. Potential links between surging ice sheets, circulation changes, and the Dansgaard-Oeschger cycles in Irminger Sea, 60-18 kyr. Palaeoceanography 15(4): 425-42.

Van Vliet-Lanoë B. 1976. Traces de glace de ségrégation en lentilles associées aux sols et phénomènes périglaciaires fossiles. Biuletyn Periglacjalny (Lodz) 26:4255. In French.

Van Vliet-Lanoë B. 1986. Le pédocomplexe du dernier glaciaire (de 125000 à 75000 B.P.). Variations de faciès et signification paléoclimatique du sud de la Pologne à l'ouest de la Bretagne. Bulletin de l'Association française pour l'étude du Quaternaire (Paris) 12:139-50. In French.

Velichko AA. 1992. Correlation of the Late Pleistocene events within glaciated areas of Northern Hemisphere. In: Frenze B, Pecsi M, Velichko AA, editors. Atlas of Palaeoclimates and Palaeoenvironments of the Northern Hemisphere. Late Pleistocene-Holocene. Budapest: Geographical Research Institute, Hungarian Academy of Sciences. p 101-05.

Voelker AHL, Grootes PM, Nadeau M-J, Sarnthein M. 2000. Radiocarbon levels in the Iceland Sea from 25$53 \mathrm{kyr}$ and their link to the Earth's magnetic field intensity. Radiocarbon 42(3):437-52.

Wang YJ, Cheng H, Edwards RL, An ZS, Wu JY, Shen C-C, Dorale JA. 2001. A high-resolution absolutedated Late Pleistocene monsoon record from Hulu Cave, China. Science 294(5450):2345-8.

Watts WA, Allen JRM, Huntley B. 1996. Vegetation history and palaeoclimate of the last glacial period at Lago Grande di Monticchio, southern Italy. Quaternary Science Reviews 15(2-3):133-53.

Zander A, Frechen M, Zykinac V, Boenigk W. 2003. Luminescence chronology of the Upper Pleistocene loess record at Kurtak in Middle Siberia. Quaternary Science Reviews 22(10-13):999-1010. 